Article

\title{
Investigation of Camphor Effects on Fusarium graminearum and F. culmorum at Different Molecular Levels
}

\author{
Aylin Gazdağlı ${ }^{1}$, Özlem Sefer ${ }^{2}$, Emre Yörük ${ }^{2, *}$, Gülin İnci Varol ${ }^{1}$, Tuğba Teker ${ }^{1}$ and \\ Gülruh Albayrak ${ }^{3}$ iD \\ 1 Institute of Graduate Studies in Sciences, Programme of Molecular Biology and Genetics, \\ Istanbul University, Suleymaniye, Istanbul 34116, Turkey; aylin.gazdagli@gmail.com (A.G.); \\ varol.gulin@gmail.com (G.İ.V.); tugba.teker@ogr.iu.edu.tr (T.T.) \\ 2 Faculty of Arts and Sciences, Department of Molecular Biology and Genetics, Istanbul Yeni Yuzyil \\ University, Cevizlibag, Istanbul 34010, Turkey; ozlemsefer@outlook.com \\ 3 Faculty of Sciences, Department of Molecular Biology and Genetics, Istanbul University, Vezneciler, \\ Istanbul 34134, Turkey; gulruh@istanbul.edu.tr \\ * Correspondence: emre.yoruk@yeniyuzyil.edu.tr; Tel.: +90-532-599-3325
}

Received: 16 October 2018; Accepted: 19 November 2018; Published: 22 November 2018

\begin{abstract}
Fusarium graminearum and F. culmorum are phytopathogens, which cause destructive diseases in cereals. Epidemics of these phytopathogens are caused by mycotoxin contamination and the reduction of crop quality. In this study, the alteration due to in vitro camphor treatment on F. culmorum 9F and F. graminearum $\mathrm{H} 11$ isolates was investigated in terms of epigenetic, cellular, and transcription levels. Camphor with different concentrations $(0.2,0.4,0.8,1,2$, and $4 \mu \mathrm{g} / \mu \mathrm{L})$ was applied to potato dextrose agar (PDA) growth media. The minimum inhibitory concentration (MIC) and the half maximal inhibitory concentration $\left(\mathrm{IC}_{50}\right)$ were calculated as 2 and $1 \mu \mathrm{g} / \mu \mathrm{L}$, respectively. hog1, mst20, CAT, $P O D, m g v 1$, stuA, and tri5 genes, which are related to various cellular processes and pathogenesis, were examined by qPCR assay. qPCR analysis showed that camphor treatment leads to the downregulation of tri5 expression but the upregulation of the remaining genes. Apoptosis and oxidative stress were confirmed via acridine orange/ethidium bromide (AO/EB) and dichlorofluorescin diacetate (DCF-DA) staining, respectively. Moreover, coupled restriction enzyme digestion-random amplification (CRED-RA) assay, used for DNA methylation analysis, was carried out to evaluate epigenetic alterations. The decrease in genomic template stability (GTS) values, which resulted due to the alterations in random amplified polymorphic DNA (RAPD) profiles caused by camphor treatment, were detected as $97.60 \%$ in F. culmorum $9 \mathrm{~F}$ and $66.27 \%$ in F. graminearum $\mathrm{H}-11$. The outer and inner methylated cytosine profiles are determined by CRED-RA assay as type I-IV epigenetic alterations. The outcomes indicated that camphor could lead to alterations at several molecular levels of F. graminearum and F. culmorum.
\end{abstract}

Keywords: apoptosis; camphor; epigenetics; gene expression; oxidative stress

\section{Introduction}

F. graminearum and F. culmorum are species of the phytopathogenic fungi genus, Fusarium. Both species have been reported as primary causal agents of various plant diseases worldwide. In particular, F. graminearum is determined as the major causal agent of Fusarium head blight (FHB) and crown rot, particularly in China and the USA [1-5]. They are not only pathogens responsible for the destructive effects on crops and for the economic losses, but they also produce several mycotoxins, such as deoxynivalenol (DON) and zearalenone (ZEN), which are hazardous to humans and other animals $[1,6]$. 
F. graminearum is a hemi-biotrophic fungus with asexual (F. graminearum, anamorph) and sexual (Gibberella zeae, telemorph) stages. The alleles required for sexual reproduction, which are located in the genome, are MAT1-1 and MAT1-2 [7,8]. The genome size $(n=4)$ of the F. graminarum PH-1 strain, which is the reference genome, is $36.1 \mathrm{Mb}$. The PH-1 strain genome carries approximately 14,000 genes and is responsible for the synthesis of approximately 180,000 proteins. Further information on annotated genes, related to the transcription process, membrane transport system, and aggressiveness, can been accessed in GenBank [9].

F. culmorum, in comparison to F. graminearum, is a monophyletic species with an unknown sexual stage. However, in recent years, parasexual reproduction has been investigated for F. culmorum $[1,10]$. The pathogen has a wide host range, and this necrotrophic fungus is a secondary phytopathogen of FHB and crown rot. Currently, a complete annotated genome is not present in databases for F. culmorum, though partial annotations for chromosomes of the FcUK99 strain can be accessed on GenBank.

In the fight against these Fusarium species, it is crucial to develop disease-resistant plant cultivars and to use antagonistic microorganisms. However, these costly and laborious strategies require extended periods of time, as well as advanced laboratory skills and experience [11-13]. Furthermore, up-to-date, commonly used antifungal agents such as thiophanate methyl, carbendazim, and propiconazole are preferred against Fusarium species, but these species have developed resistance against such common antifungals [14-16]. So, many novel chemicals must be tested in terms of their antifungal effects. Therefore, an in vitro demonstration of fungicidal effects of essential oils obtained from plants could lead to in planta fungicide treatments as disease management.

The major components of essential oils obtained from plant extracts (kapyrrole derivatives, indole derivatives, etc.) have been used to inhibit fungal growth [17-19]. One of the major components of essential oils, camphor $\left(\mathrm{C}_{10} \mathrm{H}_{16} \mathrm{O}\right)$, is a bicyclic monoterpene ketone widely found in several aromatic plants such as Cinnamonum camphora, Piper capense, and Salvia officinalis. Even though large doses of camphor show toxicity for humans, it has been used in traditional medicine [20] and different commercial cosmetic products with limited doses. As far as we know, there is no study on the potential antifungal effects of camphor in F. graminearum and F. culmorum. In this study, camphor's effects on F. graminearum and F. culmorum in terms of the in vitro growth capacity of fungal cells, alterations of specific gene expression levels, apoptosis, oxidative stress, and camphor's epigenetic alteration capacity on fungal cells were investigated for the first time.

\section{Results}

\subsection{Antifungal Application Analysis}

Fusarium species did not show growth on potato dextrose agar (PDA) $+2 \mu \mathrm{g} / \mu \mathrm{L}$ camphor. Thus, the minimum inhibitory concentration (MIC) was determined as $2 \mu \mathrm{g} / \mu \mathrm{L}$ by common protocol for agar dilution techniques, as a reported by Irzykowska [21]. Then, the half maximal inhibitory concentration $\left(\mathrm{IC}_{50}\right)$ was calculated as $1 \mu \mathrm{g} / \mu \mathrm{L}$. This concentration was used for experiments in further studies.

\subsection{Gene Expression Analysis}

cDNAs were converted from high-quality $\left(\Delta_{260 / 280}=1.9-2.0\right)$ and a high amount $\left(0.5-2 \mu \mathrm{g} \mu \mathrm{L}^{-1}\right)$ of total RNA molecules. hog1, mst20, CAT, POD, mgv1, stuA, and tri5 gene expression levels were determined. In quantitative polymerase chain reaction (qPCR) analysis, the mean $\mathrm{E}$ (efficiency) value, which was calculated using Cp (crossing point) values related to log series of cDNAs, was obtained as $2.131 \pm 0.059$, and the mean melting score was $0.89 \pm 0.007$. In this study, both types of data showed that qPCR was applied very efficiently. The $2^{-\Delta \Delta C T}$ values $(1.241 \pm 0.16$ to $6.359 \pm 1.01)$ for experimental sets of target genes are given in Table 1. After normalization, hog1 and mst20 (associated with apoptosis), CAT and POD (responsible for oxidative stress), as well as mgv1 and stuA (liable for cell survival and viability) expressions increased, ranging from $1.826 \pm 0.28$ to $6.359 \pm 1.01$ by camphor treatment. This revealed that these genes were upregulated. The decrease of tri5 (responsible 
for mycotoxin production) expressions (from $0.349 \pm 0.02$ to $0.449 \pm 0.07$ ) was also detected (Figure 1 ). These results were found to be significantly different in statistical analysis $(p<0.05)$.

Table 1. qPCR values of this study.

\begin{tabular}{ccc}
\hline Gene & $\mathbf{2}^{-\boldsymbol{\Delta} \mathbf{\Delta C T}}$ for 9F & $\mathbf{2}^{-\boldsymbol{\Delta \Delta C T}}$ for H-11 \\
\hline hog1 (DQ065608.1) & $2.178 \pm 0.09$ & $3.965 \pm 1.42$ \\
mst20 (XM_011329927.1) & $1.821 \pm 0.29$ & $2.318 \pm 0.33$ \\
mgv1 (AF492766.1) & $1.460 \pm 0.39$ & $1.826 \pm 0.28$ \\
stuA (HG970332.2) & $1.297 \pm 0.14$ & $6.359 \pm 1.01$ \\
CAT (XM_011328072.1) & $2.512 \pm 0.22$ & $1.996 \pm 0.18$ \\
POD (XM_011329011.1) & $1.241 \pm 0.16$ & $4.280 \pm 0.94$ \\
tri5 (AY130290.1) & $0.449 \pm 0.07$ & $0.349 \pm 0.02$ \\
\hline
\end{tabular}

Camphor Applied F. culmorum 9F isolate

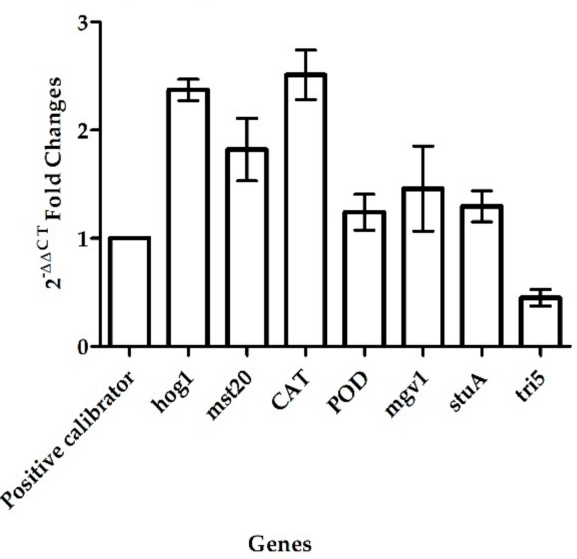

Camphor Applied F. graminearum H-11 isolate

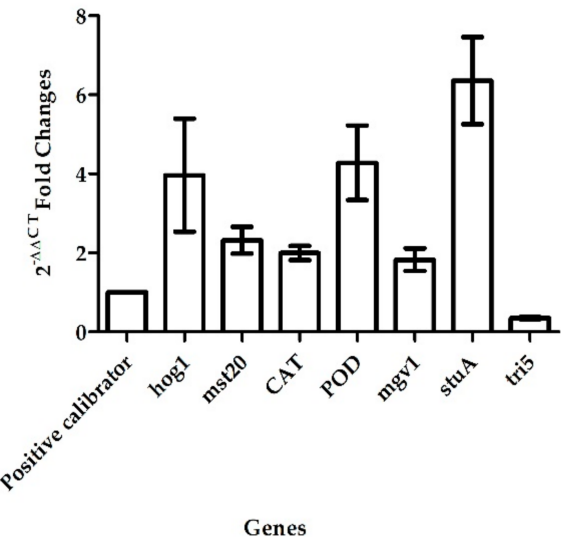

Figure 1. Fold changes in gene expressions in response to camphor.

\subsection{Staining Analysis}

The presence of late-phase apoptotic cells was demonstrated by AO/EB (acridine orange/ethidium bromide) staining. Healthy cells in control groups radiated green fluorescence dye in both Fusarium species. In camphor-treated experimental sets, light yellow- to light brown-colored mycelia showed the occurrence of a process similar to apoptosis. The fluorescence density of EB was greater than that in the experimental sets.

The presence of ROS (reactive oxygen species) activity was investigated in experimental sets with green luminescence, using DCF-DA $\left(2^{\prime}, 7^{\prime}\right.$-dichlorodihydrofluorescein diacetate) dye. No colored cells were observed in the control groups (Figure 2). Mycelial growth was identified in camphor-treated cells at the days 5,7 , and 14 of incubation.

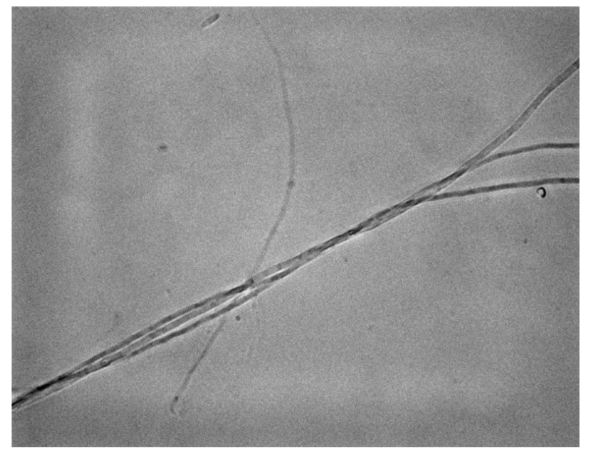

(A)

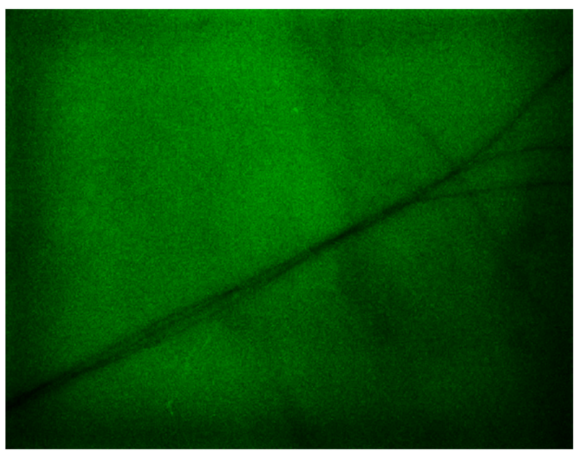

(B)

Figure 2. Cont. 


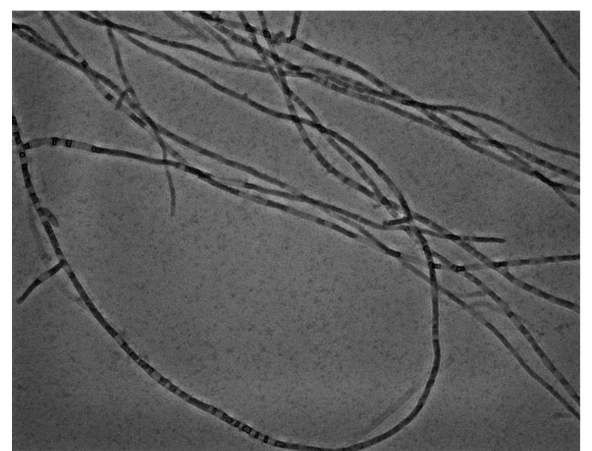

(C)

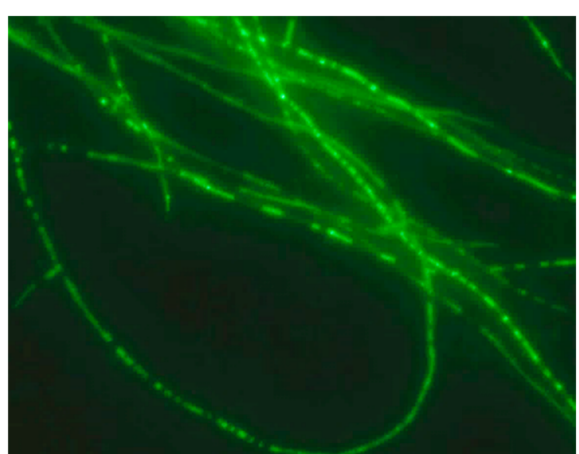

(D)

Figure 2. (B,D) Fluorescein isothiocyanate (FITC) and (A,C) daylight filter-captured profile of cells treated with camphor $(\mathbf{C}, \mathbf{D})$ and control sets $(\mathbf{A}, \mathbf{B})$.

\subsection{Antioxidant Activities and Thin-Layer Chromatography (TLC)}

Abiotic stress was confirmed by both spectrophotometrical analysis and qPCR. CAT and POD gene expression levels were high in both camphor-treated F. graminearum (H-11) and F. culmorum (9F) isolates. Upregulated $C A T$ and $P O D$ gene expression levels and enzyme activity values (significant differences; $p<0.05$ ) showed that camphor caused oxidative stress. CAT (catalase) activities were calculated as $1.73 \pm 0.6(p<0.05)$ and $4.24 \pm 2.01(p<0.01)$ for F. culmorum $9 \mathrm{~F}$ and F. graminearum $\mathrm{H}-11$ isolates, respectively. Similarly, POD (peroxidase) activities for F. culmorum 9F and F. graminearum $\mathrm{H}-11$ isolates were recorded as $1.5 \pm 0.5(p<0.05)$ and $1.5 \pm 0.5(p<0.05)$, respectively. At the end of the TLC analysis, in control sets, spots corresponding to the DON mycotoxin with an Rf (retention factor) value of 0.28 were detected. In the experimental sets, the spots appeared to be insignificant for certain samples and were not observed for other samples. Therefore, the data were obtained as a result of the inhibition of DON production by camphor.

\subsection{Coupled Digestion-Random Amplification (CRED-RA) and Random Amplified Polymorphic DNA (RAPD) Analyses}

A total of 15 primers were used for RAPD and CRED-RA analyses. No amplification product was obtained from the five oligonucleotide primers (OPA-04, OPA-05, OPA-06, OPC-04, OPC-05). However, the polymerase chain reaction (PCR) procedure worked properly for the remaining 10 oligonucleotide primers and PCR fragments were obtained in 12 experimental sets (Table 2).

Genomic template stability (GTS) analysis was carried out with 86 bands obtained from non-digested sets of $\mathrm{IC}_{50}$ and from the control groups. Minimum amplification products (5) were obtained from OPB-07, while maximum fragments (13) were detected from OPA-01. The GTS values for $\mathrm{IC}_{50}$ groups of F. culmorum $9 \mathrm{~F}$ and F. graminearum $\mathrm{H}-11$ were detected as $97.60 \%$ and $66.27 \%$, respectively. This analysis showed that camphor treatment with increasing concentrations caused a decrease in genomic stability.

Due to camphor treatment, type I-IV epigenetic alterations, which represent the outer and inner methylated cytosine profiles, were detected in this analysis. The epigenetic alterations related to HapII and MspI digestion profiles of the experimental groups are shown in Table 3.

The average polymorphisms for epigenetic alterations ranged from $2.85 \%$ to $55.7 \%$ for $\mathrm{HapII}$ and MspI analyses. Polymorphic changes based on epigenetic alterations were characterized by the band intensity and the loss or addition of a band. 
Table 2. Random amplified polymorphic DNA (RAPD) primers used in this study and total band numbers obtained in RAPD analysis.

\begin{tabular}{cccc}
\hline Primer & Sequence ( $^{\prime} \mathbf{- 3}^{\prime}$ ) & \% GC & Total Band No. \\
\hline OPA-01 & CAGGCCCTTC & $70 \%$ & 13 \\
OPA-03 & AGTCAGCCAC & $60 \%$ & 9 \\
OPA-04 & AATCGGGCTG & $60 \%$ & - \\
OPA-05 & AGGGGTCTTG & $60 \%$ & - \\
OPA-06 & GGTCCCTGAC & $70 \%$ & - \\
OPA-07 & GAAACGGGTG & $60 \%$ & 9 \\
OPA-08 & GTGACGTAGG & $60 \%$ & 7 \\
OPB-06 & TGCTCTGCCC & $70 \%$ & 8 \\
OPB-07 & GGTGACGCAG & $70 \%$ & 5 \\
OPB-09 & TGGGGGACTC & $70 \%$ & 6 \\
OPB-10 & CTGCTGGGAC & $70 \%$ & 12 \\
OPB-13 & TTCCCCCGCT & $70 \%$ & 8 \\
OPB-14 & TCCGCTCTGG & $70 \%$ & 9 \\
OPC-5 & GATGACCGCC & $70 \%$ & - \\
OPC-4 & CCGCATCTAC & $60 \%$ & - \\
\hline
\end{tabular}

Table 3. Band profiles obtained from coupled restriction enzyme digestion-random amplification (CRED-RA) analysis.

\begin{tabular}{|c|c|c|c|c|c|c|c|c|c|c|c|c|c|c|c|c|}
\hline \multirow[t]{3}{*}{ Primer } & \multirow{2}{*}{\multicolumn{2}{|c|}{ 9F Control }} & \multirow{2}{*}{\multicolumn{2}{|c|}{$\begin{array}{c}\text { 9F Experiment Total } \\
\text { Band Number }\end{array}$}} & \multirow{2}{*}{\multicolumn{2}{|c|}{$\begin{array}{c}\text { 9F Experiment Total } \\
\begin{array}{c}\text { Polymorphic Band } \\
\text { Number }\end{array} \\
\mathrm{IC}_{50} \\
\end{array}$}} & \multirow{2}{*}{\multicolumn{2}{|c|}{$\begin{array}{c}\text { 9F Polymorphism (\%) } \\
\mathrm{IC}_{50} \\
\end{array}$}} & \multirow{2}{*}{\multicolumn{2}{|c|}{ H-11 Control }} & \multirow{2}{*}{\multicolumn{2}{|c|}{$\begin{array}{c}\begin{array}{c}\text { H-11 Experiment } \\
\text { Total Band } \\
\text { Number }\end{array} \\
\mathrm{IC}_{50} \\
\end{array}$}} & \multirow{2}{*}{\multicolumn{2}{|c|}{$\begin{array}{c}\begin{array}{c}\text { H-11 Experiment } \\
\text { Total Polymorphic } \\
\text { Band Number }\end{array} \\
\text { IC }_{50}\end{array}$}} & \multirow{2}{*}{\multicolumn{2}{|c|}{$\begin{array}{c}\begin{array}{c}\text { H-11 Polymorphism } \\
(\%)\end{array} \\
\mathrm{IC}_{50} \\
\end{array}$}} \\
\hline & & & & & & & & & & & & & & & & \\
\hline & HapII & MspI & HapII & MspI & HapII & $M s p I$ & HapII & MspI & HapII & MspI & HapII & MspI & HapII & MspI & HapII & $M s p I$ \\
\hline OPA1 & 3 & 4 & 3 & 3 & 0 & 1 & 0 & 25 & 4 & 5 & 8 & 2 & 5 & 3 & 100 & 60 \\
\hline OPA3 & 5 & 7 & 5 & 6 & 0 & 1 & 0 & 14.28 & 5 & 5 & 5 & 5 & 0 & 0 & 0 & 0 \\
\hline OPA7 & 3 & 3 & 3 & 4 & 0 & 1 & 0 & 33.33 & 3 & 3 & 6 & 3 & 3 & 0 & 100 & 0 \\
\hline OPA8 & 3 & 5 & 2 & 2 & 1 & 3 & 33.33 & 60 & 2 & 4 & 2 & 3 & 0 & 1 & 0 & 25 \\
\hline OPB6 & 5 & 7 & 4 & 5 & 1 & 2 & 20 & 28.57 & 4 & 5 & 5 & 6 & 3 & 1 & 75 & 20 \\
\hline OPB7 & 3 & 4 & 3 & 3 & 0 & 1 & 0 & 25 & 4 & 4 & 4 & 4 & 2 & 2 & 50 & 50 \\
\hline OPB9 & 3 & 3 & 3 & 3 & 0 & 0 & 0 & 0 & 4 & 4 & 4 & 4 & 2 & 2 & 50 & 50 \\
\hline OPB10 & 6 & 7 & 5 & 6 & 1 & 1 & 16.67 & 14.28 & 5 & 5 & 5 & 6 & 4 & 3 & 80 & 60 \\
\hline OPB13 & 5 & 5 & 5 & 5 & 0 & 0 & 0 & 0 & 5 & 5 & 5 & 4 & 0 & 1 & 0 & 20 \\
\hline OPB14 & 3 & 2 & 1 & 2 & 2 & 0 & 66.67 & 0 & 2 & 3 & 4 & 3 & 4 & 4 & 100 & 100 \\
\hline Mean & 3.9 & 4.7 & 3.4 & 3.9 & 0.5 & 1 & 2.857143 & 18.33333 & 3.8 & 4.3 & 4.8 & 4 & 2.3 & 1.7 & 55.5 & 38.5 \\
\hline
\end{tabular}




\section{Discussion}

Isolates with high genotypic and chemotypic diversity were obtained from diseased plants cultivated in agro-ecological regions with different climatic conditions. Class B trichothecene chemotypes and molecular marker-based genotypic diversity have been studied most frequently. Chemotypes with 15-ADON and 3-ADON have been reported to be the predominating chemotypes for F. graminearum and F. culmorum, respectively [1-3]. Additionally, the regulation of mycotoxin biosynthesis in vitro and in planta has also been well studied in Fusarium spp. [22-24]. Investigations related to the discovery of novel compounds can lead to the discovery of potential fungicides or chemicals with antifungal effects. These could be useful for the development of both local and global disease management strategies.

Fungicide treatment in F. graminearum- and F. culmorum-infected fields presents a promising strategy for dealing with FHB and crown rot epidemics. However, resistance developing by both Fusairum species against the common fungicidal compounds, which are used in crops, is an observed difficulty. Genetic diversity becomes effective for the development of resistance to these chemicals [14-16,25]. Currently, there is limited knowledge about the epigenetic or biochemical background of this resistance. In this study, the antifungal effects of camphor-one of the compounds of plant essential oils-were investigated by molecular approaches.

Camphor can be a promising agent for in vitro and/or in planta disease management, because it is less harmful to human and animal health. So far, the antifungal potential of some chemical compounds derived from plant or bacteria have been investigated in Fusarium species. However, comprehensive data were not obtained from those studies based on the investigation of the macroconidium reproduction capacity, radial growth rate, and inhibition of mycotoxin biosynthesis alterations $[17,18,25,26]$. Gene alterations, which are related to important processes in the fungal life cycle, the detection of apoptosis-like processes, and the determination of the presence of oxidative stress, have not been investigated in F. graminearum and F. culmorum. In this study, camphor's potential antifungal effects were investigated in F. graminearum and F. culmorum for the first time in terms of gene expression, epigenetics, and cellular analysis.

In this study, the MIC values for these two species were found at moderate levels as compared with some other plant essential oils such as eugenol, vanillin, dimethyl pyrrole, etc. In addition, a relatively higher level of mycotoxin inhibition was also detected via qPCR $[17,18,26-30]$. IC 50 values of $1 \mu \mathrm{g} / \mu \mathrm{L}$ were used in further studies.

Alterations in hog1, mst20, CAT, POD, mgv1, stuA, and tri5 expressions were evaluated in this study for the first time for the antifungal effects of camphor in terms of molecular genetic analysis. hog1 (MAP kinase) and mst20 (serine/threonine-protein kinase) genes are associated with apoptosis-like processes. The expression of $C A T$ (catalase) and $P O D$ (peroxidase) genes is regulated as a response to oxidative stress. $m g v 1$ (mitogen-activated protein kinase gene) and stuA (apses transcriptional factor gene) are essential genes required for cell viability and survival. tri5 (trichodiene synthase gene) encodes the enzyme which is responsible for the first reaction of the tri5 gene cluster.

$m g v 1$ and $s t u A$, which can be accepted as positive calibrator genes for changes in homeostasis of the fungal life cycle, showed upregulation as a response to camphor treatment. These data are important since they represent the potential for physiological alterations in camphor-treated Fusarium isolates. The presence of an apoptosis-like process was detected by gene expression analysis and fluorescence analysis. In addition, antioxidant activity by spectrophotometer assay was used to show the presence of oxidative stress. Findings showed that camphor can be a potential agent for F. graminearum and F. culmorum by triggering an apoptosis-like process and oxidative stress. Additionally, tri5 downregulation, which was demonstrated by qPCR and TLC assays, signified that F. graminearum and F. culmorum might exhibit reduced DON-producer phytopathogens via camphor treatment. In RAPD and CRED-RA analyses, both genomic template stability and epigenetic alterations were detected. A moderate level of alterations in genomic template stability and type I/IV and type II/III methylation profiles were obtained in this study $[19,30]$. However, alterations on chromosomal 
regions would increase the effects of camphor on the aggressiveness and viability of $F$. graminearum and F. culmorum. In general, it seems that camphor can be used as a useful agent with potential antifungal effects against Fusarium spp.

\section{Materials and Methods}

\subsection{Antifungal Treatment}

H-11 F. graminearum isolate was obtained from diseased corn samples in Korea by Dr. Therese Lee and 9F F. culmorum isolate was obtained from diseased wheat spike in Turkey by Dr. Berna Tunali. These isolates were used in this study. Fungal isolates were cultivated at $26 \pm 2{ }^{\circ} \mathrm{C}$ for 7 days. Experimental sets were grown on potato dextrose agar (PDA) medium supplemented with camphor (Sigma-Aldrich, St. Louis, MO, USA) with different concentrations $(0.2,0.4,0.8,1,2$, and $4 \mu \mathrm{g} / \mu \mathrm{L})$. Subsequently, $0.25 \mathrm{~cm}^{2}$ agar plugs were used for in vitro growth. MIC and $\mathrm{IC}_{50}$ values were determined by using the agar dilution technique via measuring the radial growth [21].

\subsection{Total RNA Extraction, cDNA Synthesis, and Gene Expression Assays}

Total RNAs were extracted from the 7-day-old cultures using Tri-Reagent (Sigma-Aldrich, St. Louis, MO, USA). Fresh mycelium $(50 \mathrm{mg}$ ) was homogenized with $0.8 \mathrm{~mL}$ Tri-Reagent according to the manufacturer's recommendations. Total RNA molecules were analyzed with a spectrophotometer (Thermo Fisher Scientific, Massachusetts-USA) and agarose gel electrophoresis of $0.8 \%$ agarose gel.

The mRNA molecules were converted to cDNAs using a commercial kit (Takara, Shiga, Japan). The manufacturer's protocol was followed. RNA $(4 \mu \mathrm{g})$ was used as starting material in cDNA. The synthesized cDNA molecules were diluted according to four logarithmic phases.

The changes in gene expression due to camphor treatment were investigated by qPCR analysis. The endogenous gene was $\beta$-tubulin. Fold changes in mgv1, stuA, CAT, POD, hog1, mst20, and tri5 gene expressions (which are closely related to essential cell processes in the fungal life cycle) were determined by $2^{-\Delta \Delta C T}$ formula [31] (Table 4). Primer molecules were designed using "Primer3" software in the current study. A LightCycler 480 II (Roche, Basel, Swiss) system accompanied with Sybr Green I fluorescent dye was used in the qPCR assays. The reaction mix included $1 \times$ Sybr Green mix, 0.5 pmol forward/reverse primer, and an amount of cDNA equivalent to $2 \mu \mathrm{g}$ RNA. Cycling conditions were $95^{\circ} \mathrm{C}$ for $15 \mathrm{~s}, 57^{\circ} \mathrm{C}$ for $15 \mathrm{~s}$, and $72{ }^{\circ} \mathrm{C}$ for $20 \mathrm{~s}$ with 45 cycles. The pre-denaturation step at $95^{\circ} \mathrm{C}$ for $2 \mathrm{~min}$ and a cooling step at $40^{\circ} \mathrm{C}$ for $30 \mathrm{~s}$ were also carried out. Experiments were repeated at least three times.

Table 4. Primers used in this study.

\begin{tabular}{ccc}
\hline Primer & Primer Sequence $\mathbf{( 5}^{\prime} \mathbf{- 3}^{\prime} \mathbf{)}$ & Size (bp) \\
\hline betaF/betaR & agggtcattacaccgagggt/gtaccaccaccaagagagtgg & 121 \\
MgvRTF/MgvRTR & aggttcaacgattccgacag/gaccattaccctgaggcaga & 100 \\
StuARTF/StuARTR & gccctactggatacgatca/ttgccttctagggacattgg & 100 \\
Hog1F/Hog1R & cctggcaaaaatacgacgtt/tgatggagaattggttgacg & 117 \\
PodrtF/PodrtR & tggatcaaggacattggtga/gttggtagcatcctgctggt & 117 \\
tri5fullF/tri5fullR & atggagaactttccaccgagtatt/agtccatagtgctacggataaggttcaa & 469 \\
CatrtF/CatrtR & aattccacgttcgttcgtc/ccatactaggctcgctttgc & 130 \\
Mst20rtF/Mst20rtR & cctgaaaaggaacgacgaga/gccagcatgatggaatttct & 117 \\
\hline
\end{tabular}

\subsection{Fluorescence Microscopy Assays}

The apoptotic and oxidative stress effects of camphor on F. graminearum and F. culmorum were evaluated with AO/EB and DCF-DA staining by using fluorescence microscope. In AO/EB dual staining, mycelia from 7 days were harvested by centrifuging at 14,000 rpm for $3 \mathrm{~min}$. The cells were washed twice with $1 \times$ phosphate buffered saline (PBS). Then, $5 \mu \mathrm{L} \mathrm{AO} / \mathrm{EB}\left(60 \mu \mathrm{g} \mathrm{mL}-1 / 100 \mu \mathrm{g} \mathrm{mL}^{-1}\right)$ mixture was added onto cells and they were incubated at $25^{\circ} \mathrm{C}$ for $5 \mathrm{~min}$. The cells were washed 
and treated with $1 \times$ PBS to remove excess AO/EB dye. Dual staining was screened by Texas RED and (green fluorescent protein (GFP) filters (Carl Zeiss, Oberkochen, Germany). In DCF-DA staining, DCF-DA was added to the cell suspension and incubated for $30 \mathrm{~min}$ at $25^{\circ} \mathrm{C}$. Then, the cells were washed twice with $1 \times$ PBS to eliminate excess DCF-DA and ROS activities were detected by fluorescein isothiocyanate (FITC) filter.

\subsection{Antioxidant Activity and TLC}

Total protein extraction from 0.5 gram of fresh mycelia from 7-day-old cultures was carried out by following the published protocol of Harris and Angal [32]. Protein concentrations were determined according to the protocol of Bradford [33]. The catalase (CAT) and peroxidase (POD) activities were obtained by spectrophotometric analysis at $240 \mathrm{~nm}$ and $470 \mathrm{~nm}$, respectively. Antioxidant enzyme activities were calculated according to the normalization of the control and $\mathrm{H}_{2} \mathrm{O}_{2}$-treated series [34,35].

TLC was used to determine DON mycotoxin [36]. First, $10 \mathrm{~mL}$ of fungal cultures were filtrated by double gauze. Then, $1 / 5$ volume of ethyl acetate was added for filtration. After centrifugation at $5000 \times \mathrm{g}$ and $4{ }^{\circ} \mathrm{C}$ for $5 \mathrm{~min}$, ethyl acetate was removed. Samples were dissolved with acetonitrile. In TLC, silica gel $60 \mathrm{~F}_{254}$ (Merck, Darmstadt, Germany), ethyl acetate:toluene (1:1), and ethanol:aluminium chloride (99:1) were used as the adsorbent, solvent, and reactive, respectively. The mycotoxin samples were co-spotted together with trichothecene standard (Sigma-Aldrich, St. Louis, $\mathrm{MO}, \mathrm{USA}$ ) on silica gels, and then run for 45-60 min. Silica gels were sprayed with reactive, and the Rf value was calculated via visualization at $365 \mathrm{~nm}$ UV light.

\subsection{CRED-RA Analysis}

gDNA was isolated from the 7-day-old cultures. Then, $100 \mathrm{mg}$ mycelia were homogenized with liquid nitrogen and a sterile pestle and mortar. Next, $500 \mu \mathrm{L}$ lysis buffer $(100 \mathrm{mM}$ Tris $\mathrm{HCl}, 100 \mathrm{mM}$ EDTA, $1 \mathrm{M} \mathrm{NaCl}, 1 \%$ SDS, and 1/500: $v / v$ : $\beta$-mercaptaethanol) was added and the homogenization was completed by grinding the samples. The sodium dodecyl sulphate-based protocol was then followed [37,38]. Qualitative and quantitative analyses of gDNA were performed via 1\% agarose gel electrophoresis and a spectrophotometer (Thermo).

The RAPD method was used for the determination of the genomic template stability of F. graminearum and F. culmorum after camphor treatment. The CRED-RA method was used in the epigenetic profiling of camphor-treated and non-treated F. graminearum and F. culmorum. A routine RAPD protocol [39] was used in GTS assays of MspI-digested, HapII-digested, and non-digested control experimental sets. In total, 15 RAPD primers were used in this study (Table 2). gDNA digestion was carried out in a reaction volume of $20 \mu \mathrm{L}$ including: $1 \times$ digestion buffer, $20 \mathrm{U}$ digestion enzyme (Takara, Shiga-Japan), and $250 \mathrm{ng}$ gDNA. The incubation was carried out at $37^{\circ} \mathrm{C}$ for $1 \mathrm{~h}$ and $65^{\circ} \mathrm{C}$ for $5 \mathrm{~min}$. The digested and non-digested samples were used in CRED-RA assays. The amplicons were electrophoresed on $1.7 \%$ agarose gels and photographed via UV light. The RAPD band sizes were evaluated using a commercial 100 bp DNA size marker (Vivantis, Jaya, Malaysia). GTS percentage and the polymorphisms percentage for methylation were calculated as reported previously [40]. Amplification products, obtained from RAPD and CRED-RA, were evaluated according to Nardemir et al. [40].

\subsection{Statistical Analysis}

The qPCRs were statistically analyzed by GraphPad Prism 5.0 (Dr. Harvey Motulsky-GraphPad Company, La Jolla, CA, USA.) software by using one-way analysis of variance (ANOVA) with Tukey's post-hoc test. A confidence interval of 0.05 was used. Standard deviation was calculated via column statistics. 


\section{Conclusions}

The results of this study showed that camphor could lead to alterations at different molecular levels including epigenetics, antioxidant, gene expression, and apoptosis processes in F. graminearum and F. culmorum. This compound could be used as a single compound or combined with different chemicals which have fungicidal effects against $F$. graminearum and F. culmorum. Trees, producing the moderate or high level of camphor, might be also planted in fields where head blight and crown rot epidemics are present. However, further analyses should be carried out via in planta assays including plant tissue culture tests and field treatments in order to investigate the fungicidal effects of this kind of essential oil. Moreover, knowledge about the effects of camphor on other phytopathogenic microorganisms should be increased.

Author Contributions: Investigation, G.A., E.Y., Ö.S., A.G., and G.İ.V.; methodology, A.G., Ö.S, E.Y., G.İ.V.; software, T.T. and Ö.S.; validation, G.A. and E.Y.; formal analysis, G.A. and E.Y.; isolate resources, G.A. and E.Y;; writing—original draft preparation, E.Y., G.A., Ö.S., T.T., and G.İ.V.; writing—review and editing, G.A.; supervision, G.A.; funding acquisition, G.A. and E.Y.

Funding: This research received no external funding.

Acknowledgments: The authors are grateful to Berna Tunali and Therese Lee for providing fungal isolates.

Conflicts of Interest: The authors declare no conflict of interest. The funders had no role in the design of the study.

\section{References}

1. Miedaner, T.; Cumagun, C.J.R.; Chakraborty, S. Population genetics of three important head blight pathogens Fusarium graminearum, F. pseudograminearum and F. culmorum. J. Phytopathol. 2008, 156, 129-139. [CrossRef]

2. Matny, O.N. Fusarium head blight and crown rot on wheat \& barley: Losses and health risks. APAR 2015, 2, 38-43. [CrossRef]

3. Pasquali, M.; Migheli, Q. Genetic approaches to chemotype determination in type B-trichothecene producing Fusaria. Int. J. Food Microbiol. 2014, 189, 164-182. [CrossRef] [PubMed]

4. Goswami, R.S.; Kistler, H.C. Heading for disaster: Fusarium graminearum on cereal crop. Mol. Plant Pathol. 2004, 5, 515-525. [CrossRef] [PubMed]

5. Tunali, B.; Özseven, İ.; Büyük, O.; Erdurmuş, D.; Demirci, A. Fusarium head blight and deoxynivalenol accumulation of wheat in Marmara region and reactions of wheat cultivars and lines to F. graminearum and Fusarium culmorum. Plant Pathol. J. 2006, 2, 150-156.

6. Desjardins, A.E.; Proctor, R.H. Molecular biology of Fusarium mycotoxins. Int. J. Food Microbiol. 2007, 119, 47-50. [CrossRef] [PubMed]

7. Kerényi, Z.; Moretti, A.; Waalwijk, C.; Olah, B.; Hornok, L. Mating type sequences in asexually reproducing Fusarium species. Appl. Environ. Microbiol. 2004, 70, 4419-4423. [CrossRef] [PubMed]

8. Przemieniecki, S.W.; Kurowski, T.P.; Korzekwa, K. Chemotypes and geographic distribution of the Fusarium graminearum species complex. Environ. Biotechnol. 2015, 10, 45-59. [CrossRef]

9. Trail, F. For blighted waves of grain: Fusarium graminearum in the postgenomics era. Plant Physiol. 2009, 149, 103-110. [CrossRef] [PubMed]

10. Obanor, F.; Erginbas-Orakci, G.; Tunali, B.; Nicol, J.M.; Chakraborty, S. Fusarium culmorum is a single phylogenetic species based on multilocus sequence analysis. Fungal Biol. 2010, 114, 753-765. [CrossRef] [PubMed]

11. Dal Bello, G.M.; Monaco, C.I.; Simon, M.R. Biological control of seedling blight of wheat caused by Fusarium graminearum with beneficial rhizosphere microorganisms. World J. Microbiol. Biotechnol. 2002, 18, 627-636. [CrossRef]

12. Anand, A.; Zhou, T.; Trick, H.N.; Gill, B.S.; Bockus, W.W.; Muthukrishnan, S. Greenhouse and field testing of transgenic wheat plants stably expressing genes for thaumatin-like protein, chitinase and glucanase against Fusarium graminearum. J. Exp. Bot. 2003, 54, 1101-1111. [CrossRef] [PubMed]

13. Bai, G.; Shaner, G. Management and resistance in wheat and barley to Fusarium head blight. Annu. Rev. Phytopathol. 2004, 42, 135-161. [CrossRef] [PubMed] 
14. Chung, W.H.; Ishii, H.; Nishimura, K.; Ohshima, M.; Iwama, T.; Yoshimatsu, H. Genetic analysis and PCR-based identification of major Fusarium species causing head blight on wheat in Japan. JGPP 2008, 10, 110-118. [CrossRef]

15. Talas, F.; McDonald, B.A. Significant variation in sensitivity to a DMI fungicide in field populations of F usarium graminearum. Plant Pathol. 2015, 64, 664-670. [CrossRef]

16. Yang, Y.; Li, M.; Duan, Y.; Li, T.; Shi, Y.; Zhao, D.; Zhou, Z. A new point mutation in $\beta 2$-tubulin confers resistance to carbendazim in Fusarium asiaticum. Pest. Biochem. Physiol. 2018, 145, 15-21. [CrossRef] [PubMed]

17. Arif, T.; Bhosale, J.D.; Kumar, N.; Mandal, T.K.; Bendre, R.S.; Lavekar, G.S.; Dabur, R. Natural products-antifungal agents derived from plants. J. Asian Nat. Prod. Res. 2009, 11, 621-638. [CrossRef] [PubMed]

18. Sefer, Ö.; Yörük, E.; Develi, E.S.; Sezer, A.S.; Konukcu, Z. 2,4-dimetilpirol'ün başak yanikliği hastaliği etmeni Fusarium culmorum'un üzerine etkilerinin incelenmesi. IJSM 2017, 4, 103-113. [CrossRef]

19. Yörük, E. Tetraconazole leads to alterations in Fusarium graminearum at different molecular levels. Appl. Ecol. Environ. 2018, 16, 6155-6167. [CrossRef]

20. Green, B.G. Sensory characteristics of camphor. J. Investig. Dermatol. 1990, 94, 662-666. [CrossRef] [PubMed]

21. Irzykowska, L.; Bocianowski, J.; Baturo-Cieśniewska, A. Association of mating-type with mycelium growth rate and genetic variability of Fusarium culmorum. Cent. Eur. J. Biol. 2013, 8, 701-711. [CrossRef]

22. Ponts, N.; Couedelo, L.; Pinson-Gadais, L.; Verdal-Bonnin, M.N.; Barreau, C.; Richard-Forget, F. Fusarium response to oxidative stress by $\mathrm{H}_{2} \mathrm{O}_{2}$ is trichothecene chemotype-dependent. FEMS Microbiol. Lett. 2009, 293, 255-262. [CrossRef] [PubMed]

23. Bernardo, A.; Bai, G.; Guo, P.; Xiao, K.; Guenzi, A.C.; Ayoubi, P. Fusarium graminearum-induced changes in gene expression between Fusarium head blight-resistant and susceptible wheat cultivars. Funct. Integr. Genom. 2007, 7, 69-77. [CrossRef] [PubMed]

24. Scherm, B.; Orru, M.; Balmas, V.; Spanu, F.; Azara, E.; Delogu, G.; Hammond, T.M.; Keller, N.P.; Migheli, Q. Altered trichothecene biosynthesis in TRI6-silenced transformants of Fusarium culmorum influences the severity of crown and foot rot on durum wheat seedlings. Mol. Plant Pathol. 2011, 12, 759-771. [CrossRef] [PubMed]

25. Kazan, K.; Gardiner, D.M.; Manners, J.M. On the trail of a cereal killer: Recent advances in Fusarium graminearum pathogenomics and host resistance. Mol. Plant Pathol. 2012, 13, 399-413. [CrossRef] [PubMed]

26. Yaguchi, A.; Yoshinari, T.; Tsuyuki, R.; Takahashi, H.; Nakajima, T.; Sugita-Konishi, Y.; Nagasawa, H.; Sakuda, S. Isolation and identification of precocenes and piperitone from essential oils as specific inhibitors of trichothecene production by Fusarium graminearum. J. Agric. Food Chem. 2009, 57, 846-851. [CrossRef] [PubMed]

27. Yörük, E.; Sefer, Ö.; Sezer, A.S.; Konukcu, Z.; Develi, E.S. Eugenol'ün Fusarium culmorum üzerindeki etkilerinin incelenmesi. FEBED 2018, 8, 215-221. [CrossRef]

28. Zemek, J.; Košíková, B.; Augustin, J.; Joniak, D. Antibiotic properties of lignin components. Folia Microbiol. 1979, 24, 483-486. [CrossRef]

29. Boonchird, C.; Flegel, T.W. In vitro antifungal activity of eugenol and vanillin against Candida albicans and Cryptococcus neoformans. Can. J. Microbiol. 1982, 28, 1235-1241. [CrossRef] [PubMed]

30. Kollu, N.; Baireddy, V.; Sivadevuni, G.; Solipuram, M. Influence of volatile compounds and food preservatives in the management of fumonisins (B1) production by Fusarium moniliforme. Afr. J. Biotechnol. 2009, 8, 4207-4210.

31. Livak, J.K.; Schmittgen, T.D. Analysis of relative gene expression data using real time quantitative PCR and the 2- $\Delta \Delta \mathrm{CT}$ method. Methods 2001, 25, 402-408. [CrossRef] [PubMed]

32. Harris, E.L.V.; Angal, S. Protein Purifications Method: A Practical Approach, 1st ed.; IRL Press: Oxford, UK, 1989; pp. 178-186.

33. Bradford, M.M. A rapid and sensitive method for the quantitation of microgram quantities of protein utilizing the principle of protein-dye binding. Anal. Chem. 1976, 72, 248-254. [CrossRef]

34. Cho, U.H.; Park, J.O. Mercury-induced oxidative stress in tomato seedlings. Plant Sci. 2000, 156, 1-9. [CrossRef]

35. Panda, S.K.; Chaudhury, I.; Khan, M.H. Heavy metals induce lipid peroxidation and affect antioxidants in wheat leaves. Biol. Plant. 2003, 46, 289-294. [CrossRef] 
36. Cvetnic, Z.; Pepeljnjak, S.; Šegvi, M. Toxigenıc potentıal of Fusarium species isolated from non-harvested maize. Arh. Hig. Rada. Toksikol. 2005, 56, 275-280. [PubMed]

37. Niu, C.; Kebede, H.; Auld, D.L.; Woodward, J.E.; Burow, G.; Wright, R.J. A safe inexpensive method to isolate high quality plant and fungal DNA in an open laboratory environment. Afr. J. Biotechnol. 2008, 7, 2818-2822.

38. Yörük, E.; Tunali, B.; Kansu, B.; Ölmez, F.; Uz, G.; Zümrüt, I.M.; Sarıkaya, A.; Meyva, G. Characterization of high-level deoxynivalenol producer Fusarium graminearum and F. culmorum isolates caused head blight and crown rot diseases in Turkey. JPDP 2016, 123, 177-186. [CrossRef]

39. Yörük, E.; Albayrak, G. Genetic characterization of Fusarium graminearum and F. culmorum isolates from Turkey by using random-amplified polymorphic DNA. Genet. Mol. Res. 2013, 12, 1360-1372. [CrossRef] [PubMed]

40. Nardemir, G.; Agar, G.; Arslan, E.; Erturk, F.A. Determination of genetic and epigenetic effects of glyphosate on Triticum aestivum with RAPD and CRED-RA techniques. TxPP 2015, 27, 131-139. [CrossRef]

(C) 2018 by the authors. Licensee MDPI, Basel, Switzerland. This article is an open access article distributed under the terms and conditions of the Creative Commons Attribution (CC BY) license (http://creativecommons.org/licenses/by/4.0/). 